\title{
AGRICULTURAL SECTOR TRANSFORMATION IN SELECTED COUNTRIES OF SOUTH EASTERN EUROPE
}

\author{
Kushtrim Braha *1, Artan Qineti ${ }^{1}$, Ján Pokrivčák ${ }^{1}$, Sadudin Ibraimi ${ }^{2}$
}

\author{
Address: \\ ${ }^{1}$ Slovak University of Agriculture in Nitra, Faculty of Economics and Management, Department of Economics, Tr. A. Hlinku 2, 94976 Nitra, \\ Slovakia, \\ ${ }^{2}$ South East European University, Faculty of Business and Economics, Ilindenska nn, 1200 Tetovo, FYROM - Republic of Macedonia \\ *Corresponding author: Kushtrim Braha, e-mail: xbraha@is.uniag.sk
}

\begin{abstract}
Governing the process of economic transformation is one of the most prominent issues arising since the fall of the Iron Curtain. After the successful transition model of the Central and Eastern European countries and their EU accession, the main anchors of the EU enlargement are directed into the South Eastern part of the continent. Most obviously, the EU enlargement is entering into the new phase of its expansion. In this paper we evaluate the state of transformation in the agricultural sector of the potential EU members comprising countries constituting the South Eastern Europe (the Western Balkans), and Turkey. We analyze whether the significant transitional changes occurred in the agricultural sector in observed countries. The main areas of our interest involve the comparative analysis of the state of economic transformation and the income convergence, the economic importance of agriculture in the potential EU Members, impact of economic transformation on the agricultural assets, agricultural policy implications, investigation of consumption patterns and poverty prevalence.
\end{abstract}

Keywords: EU enlargement, economic transformation, agricultural sector

JEL: P21, O11, O47, N54, Q10

\section{INTRODUCTION}

The European Union has become a continental exercise in economic integration. This is the direct result of no less than six enlargements over a period of 35 years. Behind this quite stunning development, there are profound changes in the political and security landscape in Europe and the demise of communism (Pelkmans 2006). Membership in the European Union (EU) places several challenges before the potential EU Members. These countries will have to adopt the EU's acquis communautaire. In addition, they will become eligible for support from the structural funds and will benefit from the freedom of movement of goods, services, labour and capital in the common market (Huber 2004). According to Stubbs and Venancio (2009) EU accession of the Western Balkans forms both a core exit strategy for the massive international political and military presence in the region and the key principle for consolidation of stable multiethnic democratic politics and regional cooperation.

Accession into the EU will influence the citizens of the candidate countries in various ways. Doyle and Fidrmuc (2006) highlighted the utilitarian considerations as the most important determinants of support for the EU. Generally, two broad categories of effects are most important. First, the new members can take full advantage of economic integration within the European Single Market, through free movement of goods, capital and labour. Second, as the new members are relatively poor compared to the EU Member States (MS) and they are stricken with high unemployment. In some cases, have large agricultural sectors, they should benefit from redistribution within the EU channelled through the Structural and Cohesion funds and the Common Agricultural Policy (CAP).

Although the process of transformation is centred on fundamental economic changes, transition is a multidimensional phenomenon that encompasses complex structural, institutional, and behavioural adjustments that go well beyond the realm of economics (Blejer and Skreb 1997). Key steps in economic transition typically involve deregulation, privatization, and the creation of a legal system that protects property rights (Napier and Thomas 2004).

Ability to build functioning market driven economy and afterwards cope with competition constitutes the fundamentals of the EU economic integration. Carbaugh (2010) defined the economic integration as a process of eliminating restrictions on international trade, payments, and factor mobility. Moreover, Molle (2006) states that economic integration is not an objective in itself, its rationale is to serve higher objectives, both economic and of a political nature. He lists the economic welfare, peace and security, democracy and human rights as the core goals of the economic integration. 
Agriculture plays an important role in almost all potential EU members. Because of its significant size and structural deficiencies, agriculture was and is still one of the most sensitive and critical issues in the enlargement context (EC 2011). Agriculture is unlike other sectors of the economy. It is very price-sensitive. If prices go too high, the consumer suffers. If they fall too low, some farmers might suffer and be driven off the land (Watts 2008). The small-scale and fragmented nature of private farming remains a general characteristic of agriculture in the potential EU members - representing a long-term structural handicap (Volk 2010). Because of its sensitivity related to the food security, barriers to the agricultural trade will be the last obstacles before the full trade liberalization of the potential EU members and EU. Empirical studies of Bojnec and Ferto (2010) suggest that agro-food exports of the potential EU members to the EU markets are highly concentrated on a few of the most important products with trade specialization. These are mostly primary bulk raw commodities, which are related to natural factor endowments. Growing export specialization on bulk raw commodities makes export developments vulnerable to changing world market conditions, which are also causing considerable instabilities in farmers' revenues and incomes.

The main objective of this paper is to evaluate the current state of transformation in the agricultural sector of the potential EU members. Hand to hand with the overall economic transformation, agriculture is exposed to a process of the structural changes. Our interest is to investigate the impact of transitional changes on agricultural sector of the potential EU members.

\section{MATERIAL AND METHODS}

The group of the potential EU members comprising countries of the South Eastern Europe (the Western Balkans), and Turkey and is diverse in terms the state of economic development, as well as the stage of transitional process. For the purpose of comparative and comprehensive assessment we have excluded Iceland from our analysis. The main areas of comparative analyses here involve: the state of economic transformation and the income convergence, the economic importance of agriculture, impact of economic transformation on the agricultural assets, investigation of consumption pattern and poverty prevalence. Degree of economic transformation was measured by the Bertelsmann Index (BTI), evaluating market economy, political management and democracy.

\section{RESULTS AND DISCUSSION}

\section{The current state of the EU enlargement}

Dynamics of the EU accession of a candidate country is a process that is influenced by the ability of a country to cope with the formal accession criteria and the EU enlargement policy. A group of the potential EU members (Table 1) comprised in 2013 countries of the
South Eastern Europe (the Western Balkans), and Turkey.

The process of the EU integration has a long run character and begins prior to their formal accession. There is a set of pre- and post-accession conditions that potential EU members must fulfil before the formal EU accession. The Copenhagen criteria (1993) forms a broad set of conditions involving political, economical and democratic institutional capacity that each potential EU member should meet prior to the formal candidacy for the EU accession. Once the Copenhagen criteria are met, a country gains the Candidate status, which in turn enables it to start with negotiations (and possible adoption) of the EU aquis communitaire. Adoption of the national legislation to the EU legislative framework nowadays consists of overall 35 chapters.

The degree of fulfilment of the Copenhagen criteria determines the stage of integration into the EU for each country individually. Potential EU members such as Macedonia, Montenegro, Turkey, and Serbia at the current stage are nominated by the EU institutions as the EU Candidate countries, while the Albania, Bosnia and Herzegovina and Kosovo are treated as the EU Potential Candidate Countries. Despite such a differentiation, EU institutions have assured a clear EU integration perspective for the both group of countries, at the moment of fulfilment of the accession criteria.

A stage of the potential EU members towards the EU accession and development of bilateral relations are displayed in the Table 1. The Western Balkans countries and Turkey are expected to join the EU at the later date. Turkey being a country with already a long experience of the EU candidacy (applied for membership on 1987) remains a "neuralgic" issue of the EU enlargement. On the other hand, despite the fact that Macedonia has been the first country from the Western Balkans to sign the Stabilisation and Association Agreement (SAA) in 2001, the dispute with Greece due to the country's name, influenced significantly dynamics of its potential EU accession. Montenegro made the largest leap toward the EU integration since its independence in 2006, initiating the accession negotiations in the mid-2012. During the recent years, Albania went through internal political kink, influencing the slowdown path on the way of its EU accession.

However, the most recent events related to the EU enlargement show a dynamic evolution, practically evolving on the "daily basis". A successful path of Croatia towards the final accession was followed by the gains of Serbia and Albania - expecting the status of the EU Candidate country in December 2013. Furthermore, an important event is related with establishment of the contractual relations between the EU and Kosovo. Such a process is supported by the EU Commission accomplishment of the feasibility study for the SAA, affirming a clear EU perspective for Kosovo. 
Table 1 The potential EU members and the state of their EU integration (November 2013)

\begin{tabular}{|c|c|c|c|c|c|}
\hline \multirow[t]{2}{*}{ Country } & \multirow[t]{2}{*}{ EU status } & \multicolumn{2}{|c|}{$\begin{array}{c}\text { Stabilisation and } \\
\text { Association Agreement }\end{array}$} & \multirow[t]{2}{*}{$\begin{array}{l}\text { Applied for } \\
\text { membership }\end{array}$} & \multirow[t]{2}{*}{$\begin{array}{l}\text { Accession } \\
\text { negotiation }\end{array}$} \\
\hline & & signed & in force & & \\
\hline Macedonia (MK) & Candidate & 2001 & 2004 & 2004 & - \\
\hline Montenegro (ME) & Candidate & 2007 & 2010 & 2008 & 2012 \\
\hline Serbia (RS) & Candidate & 2008 & - & 2009 & - \\
\hline Turkey (TR) & Candidate & - & - & 1987 & 2005 \\
\hline Albania (AL) & Potential candidate & 2006 & 2009 & 2009 & - \\
\hline Bosnia Herzegovina (BA) & Potential candidate & 2008 & - & - & - \\
\hline Kosovo (KS) & Potential candidate & - & - & - & - \\
\hline
\end{tabular}

Source: Own elaboration based on the data from EC (2013)

Note: (-) No effective date

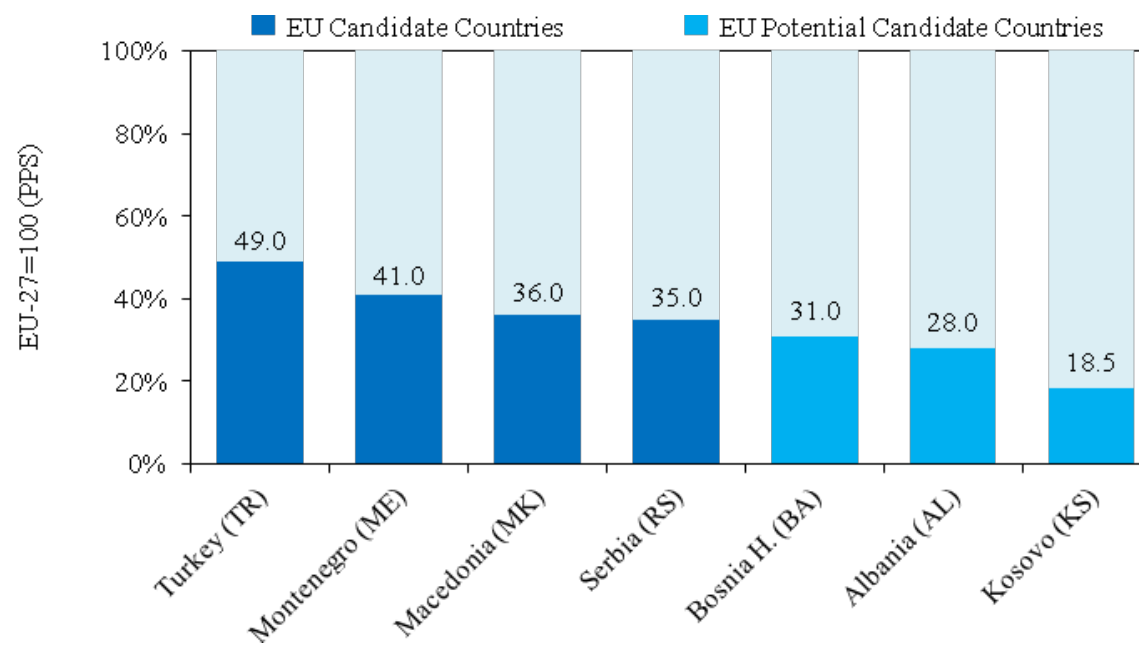

Figure 1 GDP per capita at current market prices in PPS (purchasing power standard) in the potential EU Members (2010)

Source: Own elaboration based on the data from Eurostat

Economic transformation and the "catch up" process Since the early 1990s, some of the potential EU members went through a disrupted process of economic transition. Most apparently, countries of the Western Balkans during that period went through a circle of destructive wars and ethnic conflicts - affecting significantly transitional shift into the functional market economy. However, the decade of 2000s marked the period of stabilised economic growth and accelerated economic transformation. Since then, almost all development indicators were improving significantly. Most importantly the level of income rose rapidly, despite the initial low incomes in the beginning of 2000s.

The concept of the income convergence (Barro and Sala-I-Martin 2004) is widely used to measure the decreasing trend of income disparities among the EU Member States. Although the level of income is not an official criterion for the EU accession, here we could indicatively highlight the fact that the income differentiation measured in terms of GDP per capita in purchasing power standard (PPS) (EU-27=100) corresponds with the EU classification of the potential EU members (Figure 1). We identified an increasing degree of income convergence within the group of the potential EU members. The poorer potential EU Members were growing at the faster rate than the richer ones (Figures 2a, 2b). Since the early 2000s, Kosovo as the poorest economy among the potential EU members achieved to triple its income. On the other hand Bosnia and Herzegovina and Albania doubled the level of GDP per capita. The same scope of increase in their incomes was estimated in the case of Turkey, Montenegro and Serbia, tending to mitigate the apparent income gap with the EU income average. Despite the fact that the level of income is not a formal criterion for the EU accession, here we could descriptively affirm that the EU institutional categorization between the EU Candidates and Potential Candidates follows the unwritten rule of the income differentiation. Countries with higher level of incomes tend to pursue a more advanced stage of the EU integration. Such an outcome has its rational justification, particularly taking into account that higher economic growth and the level of incomes are result of the advanced degree of institutional reforms, efficient resource allocation, development of the human capital, and increasing competitiveness of the potential EU 
members. All these objectives, directly or indirectly bold the economic side of the EU acceding preconditions.

a) EU Candidate countries

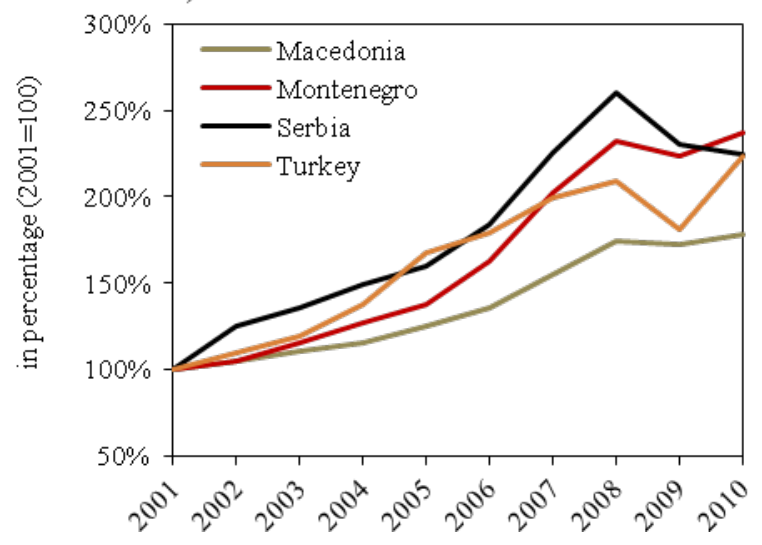

b) EU Potential Candidate countries

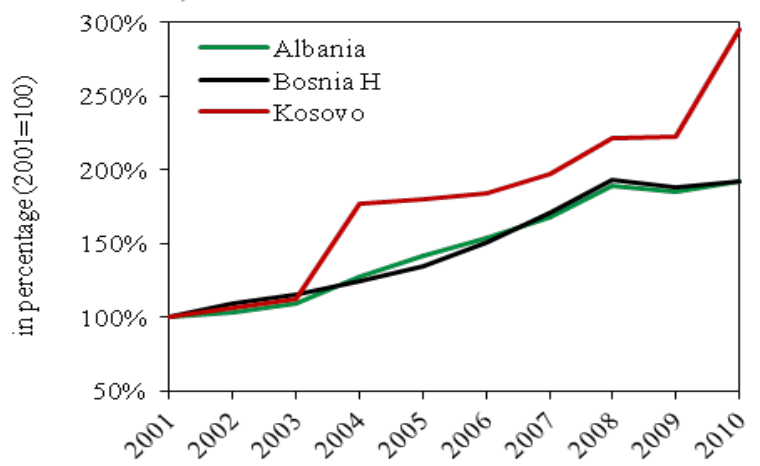

Figure 2a, 2b Dynamics of the income growth in the potential EU members (2001-2010)

Source: Own elaboration based on the data from Eurostat

\section{Economic transformation and welfare implications}

Comparative assessment of the level of income and the state of economic transformation employed in this paper indicates existence of a strong relationship between both indicators. Our analyses involved the comparison of the potential EU members and selected New Member States of the fifth EU enlargement and Croatia (EU NMS-11). Results show the transformation process importance. There is clear evidence of a strong correlation between degree of economic transformation measured by Bertelsmann Index (BTI), evaluating market economy, political management, democracy in transition countriesand the level of the income (GDP p.c.) (Figure 3).

Apparently, in economies of the EU NMS-11 the higher intensity of economic transformation led them into the accelerated income growth. Comparative analysis evidenced that the potential EU members lags behind the EU NMS-11 concerning the market and institutional reforms. However, some exceptions should be taken into account. For example, prior to its EU accession, Croatia displayed a higher degree of transformation than some of the EU NMS (such as Bulgaria, Romania, and Latvia). Nevertheless, results of our analyses regarding the degree of economic transformation were in line with the current EU categorization between the EU Candidates and Potential Candidates. Indeed, the EU Potential Candidates (Kosovo, Bosnia and Herzegovina and Albania) were displaying a lower degree of economic transformation than the Candidate countries, despite the fact that the gap between these economies and some of the EU Candidates (Serbia, Macedonia and Montenegro) is becoming narrow.

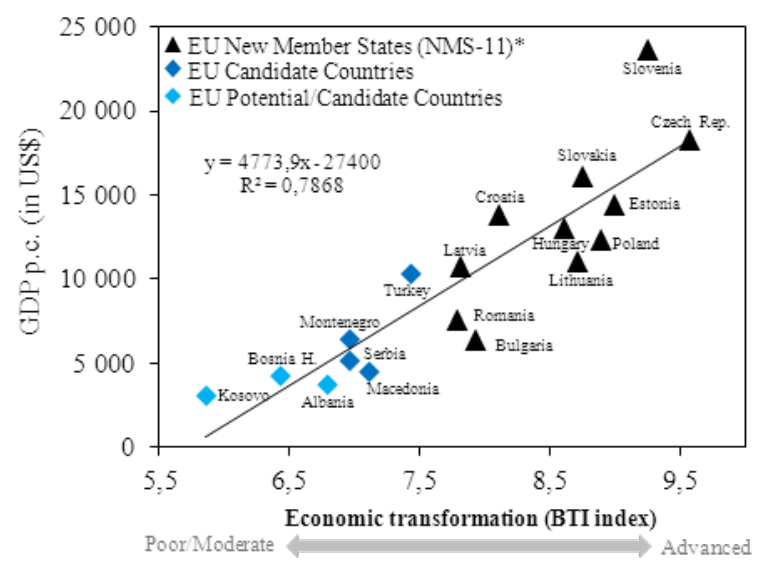

Figure 3 Relationship between the economic transformation and income (2010)

*NMS-11 selected NMS countries of the fifth EU enlargement and Croatia

Own elaboration based on the data from IMF

\section{Agricultural sector in transition and the EU accession}

Despite the fact that majority of the potential EU members see themselves in the advanced stage of the economic transition, in most of them agriculture plays an important role. Importance of agriculture in these countries is multidimensional, and its impact is widespread in the structure of national production, employment, and trade pattern. Most obviously, agriculture will continue to have a strong impact during the incoming period considering its current influence on the main macroeconomic accounts.

Theoretical framework and empirical evidence underlines a close relationship between the potential of agriculture and the geographic predispositions of an economy. In the case of the Western Balkan and Turkey (Table 2) we could evidence the fact that the Utilized Agricultural Area (UAA) constitutes significant share of the total land area, and varies from the highest $65.2 \%$ in Serbia to the lowest 32.2\% in Bosnia and Herzegovina. Arable land constitutes the most significant portion of the UAA. The climate and geographical constraints are most visible in the case of Montenegro, where the large share of grassland in UAA composition (87.5\%) was observed in 2010 .

\section{Economic importance of the agricultural sector}

Almost all potential EU members have a common feature - a large agricultural sector. Our investigation (Table 2, Figure 4) affirms a high contribution of agriculture in national accounts (GDP), total employment, and trade accounts. Importance of the agricultural sector in the potential EU members is several times higher than in the EU-27. For example, in Albania we noticed the highest share of agriculture in both GVA and employment (20.3\% in GVA and 55.3\% in employment). The double digit significance of agriculture contribution in GVA is estimated also in the case of Kosovo (14.5\%), Macedonia 
(11.6\%), Serbia (10.8\%), and Montenegro (10.0\%). While in the remaining group of the potential EU members, agricultural contribution to GVA varies from 8.6\% in Bosnia and Herzegovina to $4.4 \%$ in Turkey. Most obviously, the pattern of the agricultural involvement in the production side of the potential EU members is significantly above of that of the EU-27 (1.7\%).

While observed economies display a natural agricultural potential, their trade pattern indicates underutilization of the agricultural resources. The agricultural trade accounts of the potential EU members indicate a similar tendency of development to that of the income growth. Since 2004, a fourfold growth of the agricultural exports was estimated in the case of Kosovo, and Bosnia and Herzegovina, despite the significant deficit in the agricultural trade balance. Consequently, Macedonia, Serbia and Montenegro improved expansively their agricultural export performance marking a threefold increase of their agricultural exports since 2004. Since that period, Serbia became a net agricultural exporter, raising the important role of agricultural sector in diminishing total trade deficit. Agricultural exports were captured about a quarter (22.2\%) in the case of Serbia, and between $10.5 \%$ and $16.9 \%$ in Macedonia, Montenegro, and Turkey of their export. On the other hand, the EU potential Candidate countries such as Albania, Kosovo and Bosnia and Herzegovina estimated a lower contribution of agricultural exports (7\% and 8\%) into the total exports.

Further we found, that less developed economies (Kosovo, Bosnia and Herzegovina, Albania) and agriculturally less endowed countries (Montenegro) displayed the highest contribution of the agricultural imports into their total imports. Such high contribution of agricultural and food related goods shows a high dependency on the imports - which in turn may exposes these economies into the greater price transmitting vulnerability as the result of the recent global food price volatility.

The role of agriculture in the potential EU members is increasingly high in terms of employment. Employment pattern of these economies (Figure 5) indicates that agriculture is employing over a half of the labour force in Albania (55.3\%). Its impact is visibly evident as well in the case of Turkey (26.1\%), Serbia (22.3\%) and Macedonia (19.1\%). Other potential EU members have somehow lower share of employment in the agricultural sector, but still significantly higher than the EU level (5.1\%). Basically, the large agricultural contribution in employment of the potential EU members indicatively gives a partial answer on degree of structural changes taking place in each country individually.

Table 2 Importance of agriculture in the potential EU members (2010)

\begin{tabular}{|c|c|c|c|c|c|c|c|}
\hline \multirow[t]{2}{*}{ Country } & \multirow{2}{*}{$\begin{array}{c}\text { Utilized } \\
\text { agricultural } \\
\text { area (UAA) } \\
\text { ('000 ha) }\end{array}$} & \multirow{2}{*}{$\begin{array}{c}\text { UAA as } \\
\text { proportion } \\
\text { of total area } \\
(\%)\end{array}$} & \multirow[t]{2}{*}{$\begin{array}{l}\text { Arable land, } \\
\% \text { of UAA }\end{array}$} & \multirow[t]{2}{*}{$\begin{array}{l}\text { Permanent } \\
\text { grassland, } \\
\% \text { of UAA }\end{array}$} & \multirow[t]{2}{*}{$\begin{array}{c}\text { Agriculture } \\
\text { share in GVA } \\
(\%)\end{array}$} & \multicolumn{2}{|c|}{$\begin{array}{c}\text { Agro-products } \\
\text { as a share of trade } \\
(\%)\end{array}$} \\
\hline & & & & & & Exports & Imports \\
\hline Macedonia (MK) & 1,120 & 43.6 & 41.4 & 49.3 & 11.6 & 16.9 & 12.8 \\
\hline Montenegro (ME) & 516 & 37.3 & 36.6 & 87.5 & 10.0 & 15.3 & 24.5 \\
\hline Serbia (RS) & 5,051 & 65.2 & 64.8 & 28.6 & 10.8 & 22.2 & 6.2 \\
\hline Turkey (TR) & 39,032 & 49.8 & 54.9 & 37.5 & 4.4 & 10.5 & 4.1 \\
\hline Albania (AL) & 1,164 & 40.5 & 48.5 & 43.4 & 20.3 & 5.7 & 17.3 \\
\hline Bosnia H. (BA) & 1,649 & 32.2 & 31.7 & 62.0 & 8.6 & 8.6 & 18.3 \\
\hline Kosovo (KS) & 593 & 54.5 & 53.0 & 21.0 & 14.5 & 8.4 & 22.6 \\
\hline
\end{tabular}

Source: Own elaboration based on the data from Eurostat, National Statistical Agencies

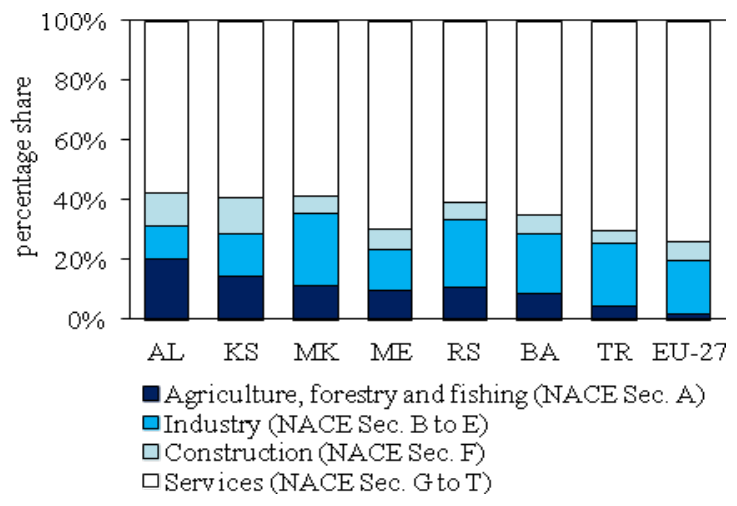

Figure 4 Gross Value Added (GVA) by sector (2010) in the potential EU member countries.

Source: Own elaboration based on the National Statistical Agencies

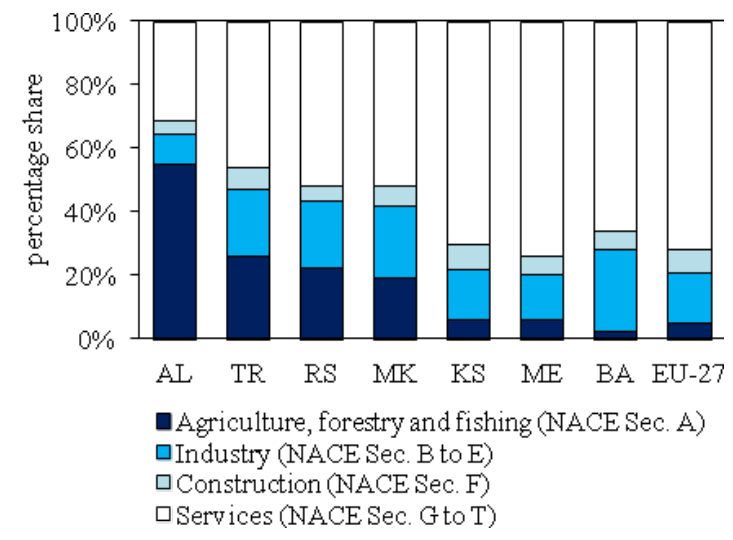

Figure 5 Employment in the main economic activities (2010) in the potential EU member countries.

Source: Own elaboration based on the National Statistical Agencies 


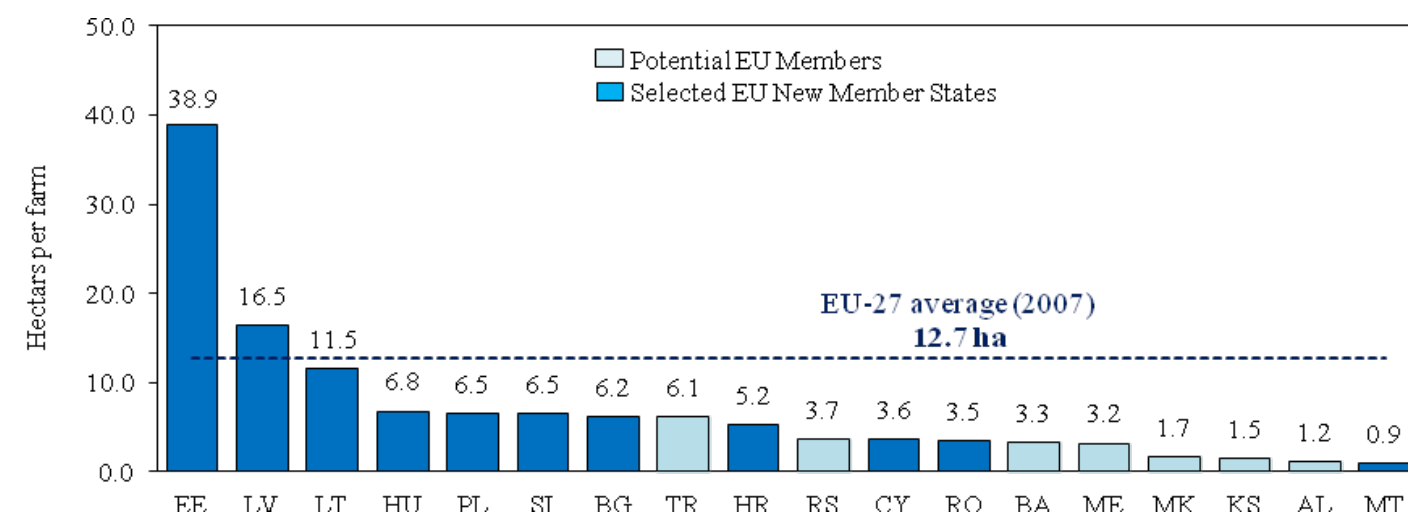

Figure 6 Average farm size (absolute value) in the potential EU members and selected NMS) Source: Own elaboration based on the Eurostat,Volk (2010)

\section{Transition and transformation of the agricultural sector}

The process of economic transition influenced agriculture directly, through the transformation of land property rights that represents one of the basic pillars of the market economy. The communist-driven farms were large sized, both in aspect of area and employment. The agricultural sector as a whole was built as a single firm having a central planner in the hub of such system. However, since the fall of the Iron Curtain, changes took place all over the Europe. Countries, we investigate in this paper, were part of such transformation, and their agricultural sector was affected as well. Due to differing types of communism taking place in potential EU members, privatization of the land went through unique types of strategies. Thus, due to the more flexible type of governing communism, the countries of the formerYugoslavia had a certain (but limited) private property rights on land. Privatization roots were at certain level already cultivated and the transformation of agricultural land was less painful. Despite such fact, agricultural land in these economies remains fragmented in smaller units. On the other hand, Albania went through the rudest communist governance characterized with a strictly controlled and isolated farming sector. After the democratic changes in 1990, Albania initiated the transition process and redistribution of the farmland. Under the land redistribution reform Albanian agricultural sector gained about 380.000 small farm operations (Zickel and Iwaskiw 1994).

Whether the process of economic transition resulted into the physical transformation of the agricultural assets? To answer this question we investigated commonly used indicator of the average size of the farm in each country individually. The key findings of our investigation (Figure 6) indicate a commonly small farm holding size in all potential EU members, ranging between 6.1 ha and 1.2 ha, which is about three times less than was the average farm size in the EU-27 in 2007 (12.7 ha). Specifically, the potential EU members' average farm size (absolute value) varies between those of Malta (0.9ha) and Bulgaria (6.2ha).
Policy issues and transformation of the agricultural sector

During the last decade there have been quite significant changes to agricultural policy in most potential EU members. In some countries budgetary transfers to agriculture have been increasing rapidly, whilst in others they have fluctuated. Empirical assessment done by Volk et al. (2012) shows that funds for supporting agriculture are relatively low. A low level of budgetary support is not unusual for countries at such a level of economic development. Indeed, it is relatively comparable with levels in the EU New Member States at the beginning of their accession preparations. A wide range of support instruments and measures are applied across the potential EU members. However, market support measures have lost importance with price and trade liberalisation during transition. Border protection is still applied in all observed economies except Kosovo, but its effectiveness is rather limited owing to free trade agreements signed in recent years (CEFTA, EU). Export subsidies are used only in Serbia. Other market support measures (market intervention, administered pricing) are less important or not applied. In recent years direct producer support has been the main element of agricultural budgetary transfers and also the major factor of growth in agriculture budgetary funds. In nearly all the countries, crop and livestock production are supported through price aids, area and/or headage payments and input subsidies, which are all forms of support that are inconsistent with the reformed Common Agricultural Policy.

\section{Transition process and structural changes}

Since the early 1990s, some of the potential EU members initiated the process of economic transition, institutional and property reforms, altogether deriving the substantial structural changes. Others went into the conflicting period of war, and followed the track of economic transition just after 2000s. Despite the time lag, there is sufficient evidence confirming that the group of the potential EU members achieved an important breakthrough in building the functional market economy.

Thus, the EBRD data affirms that contribution of the private sector in GDP apparently increased since the initial steps of the transition process (Table 3 ). Here we 
evidence, that Albania, the most hermetically isolated economy during the period of communism, made a great shift in transferring its development assets from the public management into the private ownership. Private sector in Albania contributes with more than $75 \%$ into the GDP formation. Other countries as well made a significant reallocation of resources from the public to the private sector. The size of the private contribution to GDP varies from the lowest $60 \%$ in Bosnia and Herzegovina and Serbia, to $70 \%$ in the case of Macedonia and Turkey.

Table 3 Transition indicators in the potential EU members (2010)

\begin{tabular}{lc}
\hline Country & $\begin{array}{c}\text { Private sector } \\
\text { GDP share, in \% }\end{array}$ \\
\hline Macedonia (MK) & 70.0 \\
Montenegro (ME) & 65.0 \\
Serbia (RS) & 60.0 \\
Turkey (TR) & 70.0 \\
Albania (AL) & 75.0 \\
Bosnia H. (BA) & 60.0 \\
Kosovo (KS) & 70.0 \\
\hline Source: Own elaboration based on the data from EBRD (2010)
\end{tabular}

\section{Consumption pattern}

The consumption pattern of the households in given economy should indirectly indicate the level of development. Theoretical framework affirms that fulfilment of the basic needs such as a food and housing tend to take greater share of incomes in the developing economies. Based on the pattern of the household consumption of the potential EU members in 2010 (Figure 7) we could categorize these economies at least into two main groups. Firstly, Kosovo represents a sui generis within the group of the potential EU members, mainly because the basic needs (food and housing) acquire here more than $70 \%$ of the total household expenditures. Despite the significant rise of incomes since early 2000s, in the case of Kosovo we noticed, that demand for food over the long-run period remained nearly inelastic. Particularly, Kosovo households spend $36.5 \%$ of their incomes for the food and $34.9 \%$ for the housing related expenditures in 2010. The large share of expenses for housing is driven by two major factors, the post-war reconstruction, as well as the traditional habits of the country's consuming behaviour. Similar pattern related to the housing expenditure is indicated also in the case of Turkey.

The second and the largest group of countries, consisting of Albania, Macedonia, Montenegro, Serbia, Bosnia and Herzegovina, and Turkey, shows that large share of their household incomes are dedicated for the food consumption, varying from the highest $47.6 \%$ in Albania to the lowest 23\% in Turkey. Common feature of all potential EU members is that about two thirds of total consumption were spent on food and housing. While according to the EU-27 average consumption pattern, over 55\% of the household incomes were spent in 2010 for the advanced needs such as recreation and culture, education, health and other needs.

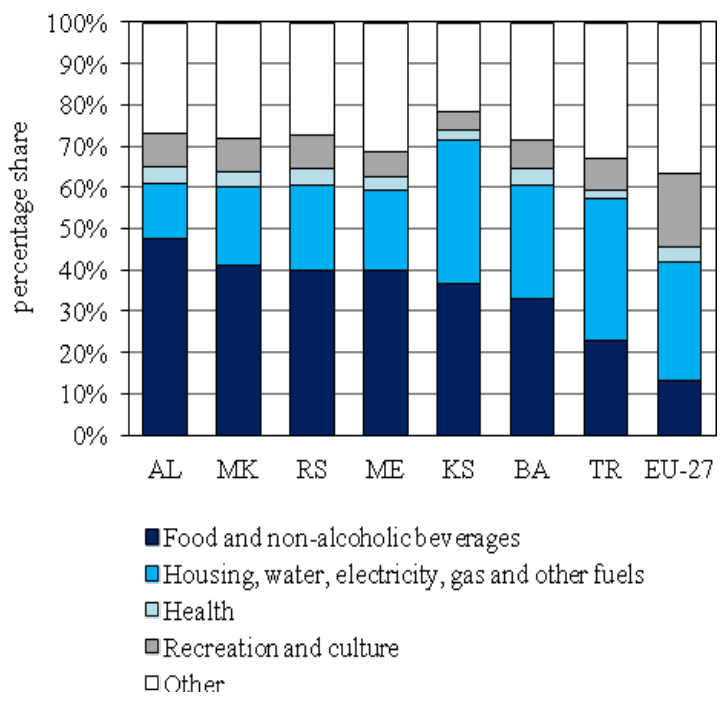

Figure 7 Consumption pattern in the potential EU members and EU-27 (2010)

Source: Own elaboration on based on the Eurostat, Statistical Agencies

\section{Poverty and income inequality}

Consumption pattern is significantly influenced by the level of income in the investigated economies. Despite the obvious welfare improvements since the beginning of transitional process, in some of the potential EU members we found a worrisome extent of poverty in 2008 (Table 4). The most noticeable level of poverty was present in Kosovo. According to the KAS (2009) it was estimated that $34.5 \%$ of Kosovo's population lived below the poverty line, with $12.1 \%$ of the population living below the extreme poverty line. However, Kosovo is not the only potential EU member facing the high poverty prevalence. Evidence from the World Bank poverty report (Table 4) affirms that significant share of population in other EU Candidates such as Macedonia (19.0\%) and Turkey (17.1\%) coped in 2007 with worrisome poverty prevalence. Evidently, the EU Potential Candidates (Albania and Bosnia and Herzegovina) as well cope with a high poverty, varying from $14.0 \%$ to $12.4 \%$.

Table 4 Poverty in the potential EU members

\begin{tabular}{|c|c|c|c|c|}
\hline \multirow[t]{2}{*}{ Country } & \multicolumn{2}{|c|}{$\begin{array}{l}\text { Poverty headcount } \\
\text { ratio (2008) }\end{array}$} & \multirow{2}{*}{$\begin{array}{c}\text { Poverty } \\
\text { headcount } \\
\text { ratio, } 2007 \\
\text { (\% pop.) }\end{array}$} & \multirow{2}{*}{$\begin{array}{c}\text { GINI } \\
\text { index } \\
(2008)\end{array}$} \\
\hline & $\begin{array}{c}\text { at } \\
\text { US\$2 }\end{array}$ & $\begin{array}{c}\text { at } \\
\text { US\$1.25 }\end{array}$ & & \\
\hline Macedonia & 4.3 & 0.3 & 19.0 & 44.2 \\
\hline Montenegro & 0.2 & 0.1 & 8.0 & 30.0 \\
\hline Serbia & 0.7 & 0.1 & 6.0 & 28.2 \\
\hline Albania & 4.3 & 0.6 & 12.4 & 34.5 \\
\hline Bosnia H. & 0.2 & 0.0 & 14.0 & 36.2 \\
\hline Kosovo & 34.5 & 12.1 & 45.0 & 30.0 \\
\hline
\end{tabular}

Source: Own elaboration on based on the data from World Bank (WDI), KAS

One of the implications of the economic transition is related to the income distribution. In particular, privatization of the state-owned assets is said to add a stimulus on increasing of the income gap between the different levels of society. However, in the case of the 
potential EU members we evidence the moderate degree in the income inequality in 2008 (measured by the GINI index), despite the straightforward constraints related to the case of Macedonia.

\section{CONCLUSION}

The potential EU members in 2013 represent a diverse group of economies. Despite the fact that level of income is not a criterion for the EU accession, in this paper we were arguing that higher degree of economic transformation may contribute into improvement of income and welfare. Successful experience of the EU NMS-11 should be considered as an encouraging signal for the potential EU members to enhance market driven reforms. Obviously, the EU enlargement criteria should serve as a proxy for the further enhancement of the transformation process.

The role of agriculture in the potential EU members is prominent regarding its contribution to the national production. The share of agriculture in GVA is significantly higher than in the EU MS, and varies from $20.3 \%$ in Albania to $4.4 \%$ in Turkey. Agriculture evidently remains a significant sector in the potential EU member countries. The importance of agriculture is evidenced in the employment pattern. In 2010, agriculture employed over $55 \%$ of the workforce in Albania, 26\% in Turkey, and 22\% in Serbia.

Despite availability of agricultural resources and favourable climatic conditions, we evidenced underutilization of the agricultural potential in some of the less developed potential EU members. Underutilization of potential in these countries brought their agriculture to the subsistence level. Taking into account chronically high unemployment in some of the potential EU members (Kosovo, Macedonia and Bosnia and Herzegovina), then agriculture become more important. Employment opportunities derived from the efficient utilization of agricultural sector should lead this countries into successful mitigation of such a structural constrains.

The pattern of agricultural trade in the potential EU members has a common denominator. Excluding Serbia, the remaining group of countries are net importers. Significantly high share of agricultural imports indicates a higher exposure on the price volatility, in particular rising concerns on food security. A worrisome degree of the poverty prevalence indicates a need for the action of the national policymakers. The role of agriculture in ensuring food security is crucial, and therefore it should gain prioritized treatment and governmental support.

The shift from the centrally planned governance to the market-driven economy influenced directly the agricultural assets. Empirical evidence in this paper indicates that the process of economic transition brought a sharp fragmentation of the agricultural land in the potential EU members. The average agricultural farm size of potential EU members is three times smaller than was the EU average farm size in 2007. The potential EU members' average farm size (absolute value) varies between those of Malta (0.9ha) and Bulgaria (6.2ha).
Land fragmentation is an outcome of the property rights transformation and will require a sufficient time until the efficient and sustainable farm units will be established. Support to agricultural sector remains weak in the potential EU members, despite substantial changes in policy approach during the last decade. A very low budgetary support is a common deficiency of the agricultural sector on its way to become sustainable. Direct producer support payments were key source of governmental support allocations.

The analysis of consumption pattern clearly reflects differences in the income levels. Despite the significant increase of income since beginning of the economic transition, Kosovo's expenditure pattern is characterized with large share of expenditures devoted to food consumption (36.5\%) and housing (34.9\%). The major group of the potential EU members (Albania, Macedonia, Montenegro, Serbia, Bosnia and Herzegovina, and Turkey) were displaying significantly large share of the food expenditures in household incomes. Food expenditures in 2010 reached $47.6 \%$ in Albania to $23 \%$ in Turkey of their household incomes.

\section{REFERENCES}

BARRO, R., SALA-I-MARTIN, X. (2004). Economic Growth. Massachusetts: The MIT Press, 2nd ed., 652 p. ISBN 0-262-02553-1

BLEJER, M., SKREB, M. (1997). Macroeconomic stabilization in transition economies. Cambridge: Cambridge University Press, 338 p. ISBN 978-0-52102535-5.

BOJNEC, Š., FERTÖ, I. (2010). Southeastern European agrofood trade specialization. In Eastern European Economics, Vol. 48, No. 3, pp. 22-51. ISSN: 00128775, doi: http://dx.doi.org/10.2753/EEE0012-8775480302

CARBAUGH, R. (2010). International economics. Mason: South-Western College Pub, 13th ed. 556 p. ISBN 978-1439038949.

DOYLE, O., FRIDMURC, J. (2006). Who favours enlargement? Determinants of support for EU membership in the candidate countries' referenda. In European Journal of Political Economy, Vol. 42, 2006, pp. 520-543, ISSN 0176-2680. doi: http://dx.doi.org/10.1016/j.ejpoleco.2005.09.008 EBRD. (2010). Structural change indicators. Available at:

http://www.ebrd.com/pages/research/economics/data/ma cro.shtml

EC. (2009). Agriculture and enlargement. Available at: http://ec.europa.eu/agriculture/enlargement/publi/brochur e_en.pdf

EC. (2013). Enlargement of the European Union.

Available at:

http://ec.europa.eu/agriculture/enlargement/index_en.htm EUROSTAT. 2013. Farm structure statistics. Available at:

http://epp.eurostat.ec.europa.eu/statistics_explained/inde x.php/Farm_structure statistics

HUBER, P. (2004). Intra-national labour market adjustment in the candidate countries. In Journal of Comparative Economics, Vol.32, No. 1, 2004, pp. 248264. doi: http://dx.doi.org/10.1016/j.jce.2004.02.008 
KAS (Kosovo Agency of Statistics). (2009). Consumption poverty in the Republic of Kosovo. Available at: https://esk.rks-

gov.net/ENG/publikimet/doc details/934-consumptionpoverty-in-the-republic-of-kosovo-in-2009

MOLLE, W. (2006). The economics of European integration: Theory, practice, policy. Burlington: Ashgate Publishing Company, 5th ed. 446 p. ISBN 978-0-75464812-5.

NAPIER, N., THOMAS, D. (2004). Managing relationships in transition economies. Westport: Praeger Publishers, 232 p. ISBN 1-56720-565-8.

PELKMANS, J. (2006). European integration: Methods and economic analysis. Essex: Pearson Education Limited, 3rd ed. 480 p. ISBN 978-0-273-69449-6.

STUBBS, P., VENANCIO, M. (2009). Compounding the Crisis? International Assistance in the Western Balkans. In Journal on European Perspectives of the Western Balkan, Vol. 1, No. 1, pp. 27-52.
VOLK, T., REDNAK. M., ERJAVEC. E. (2012). Western Balkans Agriculture and European Integration: Unused potential and policy failures? In Post-Communist Economies, Vol. 24, No. 1, pp. 111-123. doi: http://dx.doi.org/10.1080/14631377.2012.647631

VOLK, T. (2010). Agriculture in the Western Balkan Countries. In Studies on the Agricultural and Food Sector in Central and Eastern Europe, Vol. 57, 249 p. ISBN 978-3-938584-51-4.

WATTS, D. (2008). The European Union. Edinburgh: Edinburgh University Press, 336 p. ISBN 978-0-74863297-8.

WORLD BANK. (2010). World Development Indicators (WDI). Available at:

http://data.worldbank.org/topic/poverty

ZICKEL, R., IWASKIW, W. (1994). Albania: A country study. Federal Research Division. Available at: http://www.dtic.mil/dtic/tr/fulltext/u2/a279647.pdf 